\title{
SELF-GOVERNMENT IN THE CITIES OF VOLYN IN THE GRAND DUCHY OF LITHUANIA: HISTORIOGRAPHICAL REVIEW
}

\section{Bortnikova A. V.}

\section{INTRODUCTION}

Local self-government is an integral attribute of modern Western democracy, which is characterized by a wealth of forms and mechanisms of the citizens' self-realization, their participation in the exercise of power at all levels - from national to local. The problem of the historical experience of local self-government in Ukraine studying becomes especially relevant during intensive practical work of the of political reform implementation in the country, depriving the center of its uncharacteristic functions, creating conditions for effective solution of local problems on the basis of subsidiarity and democracy.

In the late middle Ages, Volyn region was a very geopolitically important region of the Grand Duchy of Lithuania, Rus, and Samogitia (GDL). Volyn, given its location on the border between European Poland and the lands of the former Kievan Rus, was a kind of transit territory as for the perception and imitation of Western European cultural heritage, which was assimilated here on the basis of old Rus cultural tradition. The conflicts and wars of the neighboring with the Ukrainian lands nations and states for their conquest often took place in Volyn. But, in addition to the devastating consequences, it contributed to the consolidation of forces in the fight against the enemy, strengthening of the defense capabilities of the cities there, forced to gain experience in self-organization of their internal life. Therefore, the study of the history of Volyn and its cities in the context of the general history of Central and Eastern Europe is of great importance for the understanding the specifics of the historical process in this region on the whole. 
In the 15th and 16th centuries the majority of the cities and towns of the Ukrainian lands that were part of the GDL were concentrated in Volyn, where the geographical factor was quite favorable for social development. Remaining as the centers of free labor in the domination of feudal relations, cities carried out strong influence on all spheres of medieval society, while adapting to the objective conditions of the existing socio-economic and political-legal environment with the existing institutions and forms of the state power organization. The liquidation of separate principalities in the Grand Duchy of Lithuania was accompanied by the rise of the cities as the centers of socio-economic and political life, and the spread of Magdeburg law in them. The questions about the legal framework and the specifics of self-government in Volyn cities are of particular interest in this regard.

In the 15th and 16th centuries the cities of the Grand Duchy of Lithuania were going through a difficult process of replacing the old customary law with the Magdeburg one. New conditions of production and the way of life required appropriate legal registration and exemption from the outdated legal norms and rules. Magdeburg law extended to Volyn cities from Germany through Poland and Lithuania, when appropriate socio-economic and political conditions similar to those of Western European cities were created. About 96 Volyn settlements, which were half of their total number have received Magdeburg law since the 15 th century to the middle of the 17 th century ${ }^{1}$. At the same time, along with Magdeburg law, gentry self-government, selfgovernment of rural, Jewish, Armenian communities with their own laws and customs functioned in Volyn at that time,

The aim of the investigation is to analyze the state of study of the problem of self-government in the cities of Volyn as part of the GDL on the basis of Magdeburg law.

\section{Research of the problem by the end of the 19th century}

The cities usually became centers of administrative management of the respective territories. The institutions of state and local

1 Заяць А. С. Урбанізаційний процес на Волині в XVI - першій половині XVII століття. Львів: Добра справа, 2003. С. 161. 
government were concentrated in them. Therefore, the achievements of medievalists in the sphere of urban planning serve as a guide for identifying the whole set of socio-political relations, where the city played a leading role, including their subordination to the Grand Ducal government, clarifying the nature of interaction between state power and city government etc.

During the period since the time when the first historical researches of the cities of Volyn have appeared a significant number of works, in which with different completeness and depth, certain aspects of city life and the organization of city self-government are covered, have been accumulated to this day. For the convenience of the characteristics of this literature, it is expedient to systematize it chronologically as follows: editions of the 17th-18th centuries; first half of the 19th century; the second half of the 19th- beginning of the 20th century; 20th century - Soviet historiography; the end of the 20th - the beginning of the 21th century. Within each stage, the research which, according to the significance of the issues raised in them, the level of sources used, etc., touched upon the research topic, was singled out.

History of Volyn to the middle of the 14th century has been first considered in the works of Polish historians of the 17th and 18th centuries - M. Dogel, A. Narushevych and others. Source historian Matej Dogel has published a valuable source - "Diplomatic Code of the Kingdom of Poland and the Grand Duchy of Lithuania"2. Diplomatic acts collected by M. Dogel concern the history of Poland, Lithuania and other states, which in certain periods included Volyn and the Volyn cities. On the rich source base of the royal and magnate-noble archives, the Polish historian A. Narushevych prepared a seven-volume "History of the Polish people", brought to $1386^{3}$. To write it, the researcher collected a huge number of sources, copies of which were published in 231 volumes,

${ }^{2}$ Codex diplomaticus Regni Poloniae et Magni Ducatus Lithuaniae in quo pacta, foedera, tractatus pacis... nunc primum ex archivis publicis eruta ac in lucem protracta exhibuntur / [ed.] M. Dogiel. T. 1, 4, 5.Vilnae, 1758-1759.

${ }^{3}$ Naruszewicz A. Historya narodu polskiego, od początku chrześciaństwa. Warszawa, 1780-1786; Londyn 1836-1837; Kraków, 1859-1860. 
which made up "Narushevych's Folders". The significant part of the materials concerns the history of Ukraine, and Volyn in particular. The work is based on a critical analysis of sources, which allowed the author to free the history of the country from the myths and legends of the past, which arose on the basis of unreliable testimony of some chroniclers. His ideal was strong royal power. At the same time, in the works of Polish historians the issues of organization of power and administration in Volyn and in the cities are touched upon in the context of the general history of Poland only in passing.

With the incorporation of Volyn into the Russian Empire after the division of the Polish-Lithuanian Commonwealth (1795), there appears an increased interest in the newly annexed region. The consequences of this interest were topographic descriptions of the region and the first attempts to write its history (V. Askochenskyi, Y. Krashevskyi, I. Potockii, A. Przezdetskyi, J. Perlstein, etc.) Information on the topography of Volyn cities, their ethno-national composition and the description of castles aroused some interest in the work of researchers.

In the first half of the 19th century there are works by such authors as M. Karamzin, D. Bantysh-Kamenskyi, M. Pogodin, S. Solovyov, M. Polevoy, S. Uvarov, M. Ustryalov, and others. The peculiarity of their research was that these scholars analyzed the history of the Grand Duchy of Lithuania mainly in the context of Russian-Lithuanian relations. New research methods were mastered, analytical literature was published, and the process of replenishing the source base for studying the history of the Grand Duchy of Lithuania continued during this period. In the absence of special scientific institutions, the main centers for the development of historical ideas and concepts were the Universities of Warsaw, Vilnyus, Moscow and St. Petersburg. Accordingly, the process of the history of the Grand Duchy of Lithuania and Volyn development can be traced mainly through the works of professors who developed this problem (I. Lelevel, M. Pogodin, M. Ustryalov). Representatives of Russian and Polish historiography, especially after the uprising of 1830-1831, clarified the place of the Grand Duchy of Lithuania in the history of Western Russia. The research of historians of that time was significantly 
influenced by political processes and events, including the incorporation of Polish lands into the Russian Empire and the Polish uprising of 1830. Therefore, it is at this time the "theory of official nationality" is gaining ground in Russia. The problem of self-government in Volyn cities was not adequately covered in the works of these authors.

From the second quarter of the 19th century in the context of the approval of the concept of "one and indivisible Russia", the attention to the history of the cities of the Grand Duchy of Lithuania is intensified; the Temporary Commission for consideration of ancient acts starts its activity. Significant work in this direction was carried out by the Archaeographic Commissions of St. Petersburg and Kyiv. Established in 1843 Kyiv's "Temporary Commission for the Analysis of Ancient Acts", played a significant role in forming the source base of research on the history of Ukrainian cities. Its leading representatives M. Maksymovych, V. Dombrovskyi, M. Ivanishev laid the scientific foundations for the study of the past of the Volyn region ${ }^{4}$. Thanks to the work of the scientists, this commission has managed to collect and preserve a huge array of ancient acts of local authorities and administration of South-Western Russia, which later formed the basis of many studies on the history of Volyn cities.

Corresponding member of the commission since 1845 has been an active Volyn local historian J. Perlstein, whose scientific work was the history of the capital of Volyn - Lutsk ${ }^{5}$. The scientist focused on the problem of the emergence of the Grand Duchy of Lithuania and the involvement of certain territories in the state formation, in particular Volyn, the importance of cities, their fortifications and castles, the introduction of local administrative management in the attached lands.

If at the early historiographical stage the characteristic feature of the local lore explorations were descriptiveness, acquaintance of the

${ }^{4}$ Максимович М. А. Собрание сочинений. Киев: Тип. М. П. Фрица, 1876. Т. 1. 847 с.; 1876.Т. 2. 524 с.; 1880. Т. 3. 743 с.; Иванишев Н. Д. Сочинения, изданные иждивением Университета св. Владимира. Отд. 1-2. Киев: Унив. тип, 1876. 463 с.

5 Перлштейн А. Луцк и его древности. Временник Московского общества истории и древностей российских. 1851. Кн. 9. С. 30-45. 
reader with social life, geographical features of the region, customs, then from the second half of the 19th century the elaboration of the problem of involving Ukrainian lands in the GDL is being deepened, the attention is being paid to the history of cities and their self-government, which can be largely explained by the formation of the source base as a result of intensified work of the Temporary Commission members in Volyn.

The second half of the 19th - early 20th century is characterized by the changes in the socio-political conditions of life in Russia: serfdom was abolished, bourgeois reforms took place in various spheres of social life, and the censorship restrictions were relaxed. However, on Ukrainian lands, on the contrary, they have been intensified. The issues of the history of Right-Bank Ukraine, Belarus and Lithuania, the interest in which grew as the result of the Polish uprising of 1863-1864, also became the subject of increased public attention. The topics of research were changed, there was a transition from the predominantly political history of the Grand Duchy of Lithuania to the study of economic, social and administrative aspects of its past. In the 60-70s of the 19th century two areas of research - historical and legal and historical and economic were formed. The researchers replenished the source base of the research through the use of regional material, in particular from the history of Volyn cities. Particular attention was paid to the issues of selfgovernment of cities under Magdeburg law, the role of this law in the life of social and national communities.

The works of representatives of the "Western Rus law" school F. Leontovych, M. Vladymiskyi-Budanov, F. Taranovskyi, M. Yasinskyi are of particular importance for the study of the problem. The characteristic of the school was the active use of comparative-historical research method, increased attention to the history of the state and law of the GDL, Ukraine and Slavs in general with an emphasis on the use of a wide range of documentary sources. Thanks to the research of this school scientists', the picture of the development of law in the territory of the Grand Duchy of Lithuania in the 14th-16th centuries was reproduced. The main objects of research were the state and legal institutions that existed in the cities of Kyiv, Volyn and Podil lands. According to their 
concept, ancient Rus law at the territory of the Grand Duchy of Lithuania remained an important factor in the formation of legal institutions, including Magdeburg law. Thus, F. Leontovych, negatively assessing the role of this law in the life of the GDL, believed that "Magdeburg order" contradicted the principles of "Rus people's life" and "led to one result the decay and economic decline of the urban community" 6 .

Famous researcher of the history of law M. VladymyrskyiBudanov in his work "German law in Poland and Lithuania"(1868) considered the system of governance on the basis of Magdeburg law of such Ukrainian cities as Kamyanets, Lviv, Kovel, Kremenets and others. He revealed the positive and negative features of the self-government of state and private cities system. The scholar has proved that the acquisition of Magdeburg law by cities did not make them truly free and they "have never completely freed themselves from the power of elders as civilian officials, from military commandants and economic tenants" A thorough analysis of the judicial system in the cities allowed him to conclude that Magdeburg law, as a rule, "provides the court in civil cases to the mayor and the council, and in criminal cases - to Vogt and Landvogt" ${ }^{\prime \prime}$.

M. Vladymyrskyi-Budanov negatively assessed the role of Magdeburg law in the history of Ukrainian cities: “... The main reason for the decline of cities in the South-Western region was precisely this system of them, that is, German - Magdeburg law"9.

According to another connoisseur of the history of Magdeburg law F. Taranovskyi, it was one of the types of city law, which in the process of its development in the middle Ages formed a separate branch of specific rights of free German communities. The emergence of this law is due to the then needs of socio-economic relations, "the development of

6 Леонтович Ф. И. Очерки истории литовско-русского права. Образование территории Литовского государства. Санкт-Петербург: Тип. В. С. Балашева, 1894. С. 373, 376.

${ }^{7}$ Владимирский-Буданов М. Ф. Немецкое право в Польше и Литве. Журнал министерства народного просвещения (ЖМНП).1868. Ч. CXXXIX. С. 468; Ч. CXL. C. $519-586 ; 772-833$.

${ }^{8}$ Там же. С. 774.

${ }^{9}$ Там же. С. 468. 
industrial labor and trade caused the demand for freedom, and its satisfaction caused the right of free court and self-government of cities as shopping centers created a free community", the scientist remarked ${ }^{10}$. In his famous study "Review of the Magdeburg Law Mementoes of Western Rus Cities" (1897) F. Taranovskyi set the task to resolve issues regarding the nature and sources of Magdeburg law, which operated in Western Rus cities in Lithuanian era, in particular the practice of using Groitskyi's and Shcherbych's collections. F. Taranovskyi proved that the whole process of Magdeburg law spreading in the south-western cities existed in the form of a special form of the foreign law reception, which developed not by law but by judicial practice through the assimilation of private popular legal collections.

In his work "Lithuanian Jews" (1883) historian-lawyer S. Bershadskyi revealed the legal status of Jews living in Volyn cities ${ }^{11}$. Based on the involvement of the Lithuanian metrics, materials of the Kyiv and Vilnius Central Archives and others, he found out the factors that contributed to the enrichment of Jews in the GDL and the reasons for their accumulation of wealth. Analyzing the legal status of Jews, S. Bershadskyi raised the issue of relations between the great Lithuanian princes and the Jews of the cities, revealed the influence of the supreme power on the organization of the taxation system, collection of trade duties, their transfer for ransom, etc. Information on the activities of customs chambers in Lutsk, Volodymyr and other Volyn cities that were in the hands of Jews, gives a clear idea of the volume of trade in the region, the distribution of customs duties, including those among city officials.

The accumulation of a large number of materials on the history of cities had a noticeable progress in the study of the history of cities in the

10 Тарановский Ф. В. Обзор памятников магдебургского права Западно-Русских городов литовской эпохи. Историко-юридическое исследование. Варшава: Тип. Варш. уч. округа, 1897. С. 2.

${ }^{11}$ Бершадский С. А. Литовские евреи. История их юридического и общественного положения в Литве от Витовта до Люблинской унии: 1388-1569. Санкт-Петербург: Тип. М. М. Стасюлевича, 1883. $431 \mathrm{c}$. 
15th and 17th centuries. Among the scientists, founders of the historical school at the University of Kyiv, there were M. Kostomarov, V. Antonovych, M. Hrushevskyi, O. Levytskyi and others. Their views on the "Lithuanian" period of the Ukrainian and Belarusian lands development sometimes differed fundamentally, but they were united by some methodological principles of research, the democratic, populist nature of the work. Researchers noted the noticeable influence of "Rus" state institutions, material and demographic resources, and spiritual culture on Lithuania. The formation of the Grand Duchy of Lithuania was influenced by the processes that took place in the regions, in particular in Volyn. Examining the impact of the Magdeburg law on the internal structure of the GDL, they generally negatively assessed its role in the development of Ukrainian cities, believing that this law was imposed on them and became an alien institution in Ukrainian life, as a result it could give them nothing but harm.

O. Levytskyi was one of the first to point out the importance of court books as sources for a comprehensive study of the past life of the western Russian regions. O. Levytskyi characterized the ancient act books of the grodski (castle) courts (state courts of first instance in large criminal cases), typical estates courts of the nobility, tribunal, magistrate and other courts as a precious heritage in the form of a colossal number of written monuments, an inexhaustible source of a long political coexistence of western Russian regions with the former Lithuanian state, and later - Poland. With the development of political life, especially from the second half of the 16th century, act books became a bright page of this life with its mental and political ferment of thoughts, parties, sects, etc., performing the same role that belongs to the press nowadays ${ }^{12}$.

V. Antonovych, a researcher of the cities of Right-Bank Ukraine, made a significant contribution to the study of the history of Volyn cities. His "Monographs on the History of Western and Southwestern Russia"

12 Левицкий О. И. О судьбе древних актових книг и собрания их в центральных архивах. Чтения в историческом обществе Нестора-летописца. Киев: [б. и.], 1896. Кн. 10. C. 11-14. 
(1885), the preface to the publication of "Acts on Cities (1432-1798)" (1869) is important for the understanding of the Magdeburg law impact on urban self-government. The scientist deduced the level of freedom of the urban state in self-government from the degree of decomposition of the urban community, the differentiation of which can be seen in the privilege of Lutsk land in 1432, where certain states were defined - on the one hand: princes ("duces"), prelates ("praelati"), boyars ("boiari"), warriors ("milites"), nobles ("nobiles"), on the other - ckmets-peasants ("homines seu kmethones") 13 . The researcher associated the disintegration of the urban community not with the spread of Magdeburg law, but with the separation of the noblemen from the community ${ }^{14}$.

The consequence of such a system of distribution of responsibilities between the bourgeoisie and the service class was the redistribution of land ownership in the rural district in favor of the polish landed gentry and the nobles with their subsequent withdrawal from the community. Having lost the rural districts in favor of the noblemen and having refused to bear arms, the communities retained the right of the court and self-government "under the guise of charters awarded to them by Magdeburg law: but this self-government had features of artificial origin after the external guarantee" $" 15$. All this, according to the historian, led to the loss of true self-governing, which the community gave. The instrument of such a loss was: 1) the appointment of individual city Vogts and the transfer to them the right to sue the city community by the princes; 2) the actual expansion of the elders' power. V. Antonovych emphasized that in the conditions of full control over the city selfgovernment by the owner in privately owned cities "The Magdeburg law only minimally guaranteed the independence of the city community". In general, assessing the role of Magdeburg law in the history of the cities,

13 Антонович В. Б. Предисловие. Архив Юго-Западной России, издаваемый Временной комиссиею для разбора древних актов, учрежденной при Киевском, Подольском и Вольнском генерал-губернаторе. Ч. V. Т. 1. Акты о городах (1432-1798). Киев: Универ. тип., 1869. С. 1.

${ }^{14}$ Там же. С. 144-145.

${ }^{15}$ Там же. С. 151 
he believed that this law "only slowed down the fall of the cities and prevented their complete disappearance" $" 16$.

In the fifth volume of the "History of Ukraine-Rus", M. Hrushevsky showed the genesis of local government in Volyn cities, the peculiarities of the Magdeburg law spread there. The nature of selfgovernment of Volyn cities determined, to some extent, the caste character of society, in particular such its peculiarity, as dependence on magnate landownership: "Volyn was the most manorial aristocratic province - the landed aristocracy completely took over the state. It was at the same time official: all senior positions were in the hands of rich families", the historian wrote ${ }^{17}$.

M. Hrushevskyi connected the introduction of Magdeburg law in Volyn with the German colonization of the Volyn principality at the end of the 13th century. It was then that in the Ipatiev chronicle the name "mestichi" (the estate of the townspeople who received Magdeburg Law) was found in contrast to the traditional definition of the inhabitants of the city as "grazhans". A few years later, in a letter from the Volodymyr city community to the community of Shtralsund, the Volodymyr consuls (councilors) are mentioned, which gave him reason to believe that Magdeburg law existed in Volodymyr, at least in part, in the first quarter of the 14th century. For the investigation of the chosen problem, M. Hrushevskyi's opinion that in Volodymyr and Lutsk certain elements of the city organization of Magdeburg law could be preserved since ancient times and be updated with later privileges is valuable, but "we do not have detailed information about them"18. M. Hrushevsky's coverage of the practice of Magdeburg law in other cities of the Grand Duchy of Lithuania and the Kingdom of Poland, first of all, Lviv, as well as Kremenets, the privately owned city of Olyka and others, allows to

16 Там же. С. 165.

17 Грушевський М. С. Історія України-Руси. Т. V. Суспільно-політичний i церковний устрій і відносини в українсько-руських землях XIV-XVII ст. Київ: Наукова думка, 1994. С. 32, 34.

18 там само. С. 32, 34, 224-225, 230. 
determine its specificity in Volyn cities - Lutsk, Volodymyr, Kovel, Ostrozhets, to which M. Grushevskyi paid less attention.

M. Hrushevskyi noted that the set of rights and responsibilities of the headman inevitably led to his interference in the affairs of urban communities, "existence in the cities of the population under the judgment of the elder, and not the magistrate... gave the headman broad ingerentia (interference - A. B.) in urban affairs, and thus opened a wide way for him and his deputies, officials, etc. to overpower everyone"19 [239, p. 350]. Magdeburg law had a particularly negative effect on the lives of the "secondary cities" that had only a "needy parody of selfgovernment." The main disadvantage of Magdeburg law for the cities was that they were excluded from the parliamentary system, did not participate in the Seim and regional Seimiks, and the laws and even city taxes were adopted without their participation. Another factor that restricted the rights of urban communities was the existence in cities of numerous jurydyks, whose population was removed from the jurisdiction of cities, which generally turned cities "into a conglomeration of misunderstandings and anomalies and instead of development gave them only a painful existence". According to M. Hrushevskyi, the introduction of Magdeburg law in Ukrainian cities had a negative impact on the fate of the bourgeoisie as a state, because, with some exceptions, "with local flashes of light and brilliance" it declines, and the reason is its dispersion "to an infinite number of small states, which, in principle, was every city community". This thesis obviously hints at the density and democracy of the urban community, which ceased to exist due to historical circumstances.

In the work "State Economy of the Grand Duchy of Lithuania under the Jagiellonians" (1901) M. Dovnar-Zapolskyi brings the economic base under the entire system of public administration and local self-government of the GDL [260, p. 32].The analysis of the system of state and local taxes and fees, including in Volyn, made by scientists, makes it possible to determine the essential characteristics of one of the

\footnotetext{
19 Там само. С. 350 .
} 
main activities of government officials at various levels - fiscal. No less important to understand the specifics of governance in the GDL, including cities, is the characterization of property relations, because the differences between "patrimony", "length of service" and "holding" resulted in their duties to the state. According to the historian, only in the period between the first and second Statutes of the Grand Duchy of Lithuania there was a complete and clear separation of personal possessions of the Grand Duke from the state ${ }^{20}$.

M. Dovnar-Zapolski's vision of the place and role of urban communities in the Grand Duchy of Lithuania was fundamentally different, claiming that "Magdeburg privileges did not artificially create urban communities, but found ready-made ground there". Denying Antonovych's position on the negative role of Magdeburg law in the fate of Ukrainian cities, he believed that Magdeburg law was not the cause of the destruction of the old Rus system; it "collapsed, turning into other forms of social life, depending on many reasons - a general reworking of social relations." The researcher noted that historians "thicken the paint too much when discussing the wrong aspects of of the urban community life under German law", moreover, it "contributed to the rapid economic growth of the city". The population of large urban centers that moved to Magdeburg law was not homogeneous, and "the new law was the middle ground that could reconcile all citizens, because it really had the features of internationalism" 21 .

Famous researcher of the history of the Grand Duchy of Lithuania M. Lyubavsky revealed the identity of the Volyn lands at the time of their entry into the Grand Duchy of Lithuania and Poland, the specifics of selfgovernment under Magdeburg law. In the fundamental work "Regional division and local government of the Lithuanian-Russian state at the time of publication of the first Lithuanian statute" (1892), M. Lyubavskyi paid much attention to the functional responsibilities of governors / elders,

${ }^{20}$ Довнар-Запольский М. В. Государственное хозяйство Великого княжества Литовского при Ягеллонах. Киев: Тип. император. ун-та Св. Владимира, 1901. Т. І. C. 137,150 .

${ }^{21}$ Там же. C. 60, 275, 276. 
including Lutsk and Volyn marshal, cornet, locksmith, city-provost and paver, etc. The scientist noted that in terms of its importance, the Lutsk headman "took the first place among the officials of the Volyn land, as their chairman and foreman" 22 . His work provides a thorough analysis of the estates of the Lutsk key and the Lutsk eldership, as well as the existing system of taxes and fees, from which the inhabitants of cities, such as "pomirne" and "kapshchyzna" (tax to the state treasury, tax in the 15th-17th centuries on the lands of the Grand Duchy of Lithuania, charged for the manufacture and sale of vodka, honey and beer from the townspeople, peasants and Cossacks) were not exempted. According to the scientist, land taxes, along with other payments and duties after receiving privileges for the Magdeburg law in the cities were often replaced by the total amount that the city had to pay to the ruler. A significant place in the monograph is given to the judicial functions of the headman and the castle government, the separation of their jurisdictions with the city courts under Magdeburg law. However, selfgovernment in the cities of the GDL was generally ignored by the researcher.

This issue is to some extent covered in another of his monographs: "An Essay on the History of the Lithuanian-Russian State up to and including the Lublin Union" (1915). The work contains a generalized description of the cities of the Grand Duchy of Lithuania management under Magdeburg law. The historian believed that the great Lithuanian princes, in granting cities this right, were guided by the prevailing belief at the time that it contributed to the successful development of cities, increasing their population and improving welfare. Among the measures that contributed to the development of cities, the scientist named the release of burghers from joint duties with the peasants, providing cities with income for building the city, freeing them from the verdicts of elders, statesmen, and all rights and customs that violate Magdeburg law. The researcher determined the nature of city self-government, its

22 Любавский М. К. Областное деление и местное управление Литовско-Русского государства ко времени издания первого Литовского статута. Исторические очерки. Москва: Университет. тип., 1892. С. 211-213. 
structure and the powers of officials, but without "linking" to the specific cities. But even in this general form, his study is valuable because it shows the essential features of the organization of self-government of the city on Magdeburg law.

The system of government in the Volyn cities, including those operating on the basis of Magdeburg law, were to some extent determined by the national privileges granted by the Grand Dukes of the Volyn. Therefore, the analysis of these legal documents, conducted by leading scholars of the late19th - early 20th century is extremely important. The regional privileges guaranteed the property and personal rights of the inhabitants, consolidated the responsibilities of the Grand Dukes and, characteristically, did not interfere in the church affairs of the Orthodox lands of the GDL. The norms enshrined in the regional privileges originated from local customary law, and were also developed by administrative and judicial practice developed during the period when these lands became part of the GDL.

Scholar-lawyer and archeographer M. Yasinsky in the work "Charter of the Lithuanian-Russian state" (1889) was the first to devote a special study to the regional privileges of the Lithuanian-Russian state, defining them as "constitutional charters".

A thorough analysis of national privileges, including Volyn, was made by another well-known expert on the history of the Grand Duchy of Lithuania, jurist I. Yakubovskyi ("Zemskie Privileges of the Grand Duchy of Lithuania", 1903). According to him, the Lithuanian Zemstvo Charter showed the desire of the legislator to combine a large amount of legal material that has been accumulated at the time of issuance of new privileges. Analyzing the regional privileges, he proved that each privilege contains "traces of a number of layers, so that a small priority letter grew to a fairly large size",23.

At the end of the 19th century local lore studies, which supplement the history of Volyn cities with materials from written sources, have been

${ }^{23}$ Якубовский И. В. Земские привилеи Великого княжества Литовского. Журнал министерства народного просвещения. 1903. № 6. С. 246. 
intensified. In the 80-90's of the 19th century the exploring of O. Andriyashev, P. Ivanov on the history of Volyn from ancient times to the fourteenth century were published. Among the books of local lore the works of the teacher of the Volyn Theological Seminary M. Teodorovych on the history of Volyn cities and counties - Kremenets, Zaslavl, Volodymyr, Starokostiantyniv, Slavuta, Kovel occupy the special place. M. Teodorovych examined their socio-economic development, trade, organization of guild crafts, provides biographical data of Volyn officials ("Vladimir city of Volyn province in the connection with the history of the Volyn diocese", 1893, etc.).

Summing up the achievements of historiography of the XIX century, it is necessary to recognize that the research of scholars reproduced many aspects of the historical past of the GDL, legal and political history of Volyn cities, including cities with Magdeburg law.

\section{The coverage of the problem of self-government of Volyn cities in the scientific literature of the 20th-21st centuries}

After 1917 and in the following years none of the Soviet historians dealt with this issue virtually. Some researchers (M. Hrushevskyi, M. Dovnar-Zapolskyi, M. Lyubavskyi) quitted studying this topic under various circumstances. F. Leontovych and M. Vladymyrskyi-Budanov passed away. Many scholars went into exile (I. Lappo), and those who remained were repressed and died in the detention camps. According to the apt statement of the modern Ukrainian researcher V. Vasylenko, it was almost "lost time" for the mentioned direction of historical studies ${ }^{24}$.

In 20s of the 20th century V. Druzhchyts was engaged in the problem of self-government in the cities of the Grand Duchy of Lithuania, mainly Belarusian, on Magdeburg $\operatorname{law}^{25}$. His analysis of the

${ }^{24}$ Василенко В. О. Політична історія Великого князівства Литовського (до 1569 р.) в східнослов'янських історіографіях XIX - першої половини XX ст. Дніпропетровськ: Нац. гірн. ун-т, 2006. С. 18.

25 Дружчыц В. Магістрат у беларускіх местах 3 майдэборскім правам у XV-XVII сталецыцях. Запіскі Адделу гуманіт. навук Інстытута Беларускае культуры. Кн. 8. Працы клясы гісторыі. Т. 3. Минск: [б. и.], 1929. С. 377-458. 
structure of city government under Magdeburg law, the functioning of magistrates, the organization of the power of the Vogts, their legal powers and activities are valuable in a comparative analysis to study the history of Volyn cities.

One of the few works of this time, which deals with the socioeconomic situation of Ukrainian cities, is the work of I. Krypyakevych "History of Ukraine" (1938). I. Krypyakevych departs from the negative assessment of Magdeburg law in the fate of Ukrainian cities in it. According to the historian, the bourgeoisie in Ukraine in the 15th-16th centuries reached a fairly high level of development, and cities became an independent factor in economic life due to self-government, which gave them German law. Larger cities, such as Lviv, Kyiv, Lutsk and others, were completely independent of the state administration and freely decided their internal affairs, "they were like small republics in their walls" 26 . Smaller cities and towns were subject to their masters, but still the burghers themselves chose a leader, could show a fairly wide range of activities and feel free and independent people. Thanks to the self-government of the city developed various areas of industry and established extensive trade, reached a significant wealth and culture. Since the mid-20s to 40 s of the twentieth century the specialist in the history and law of Ukrainian cities of the Middle Ages and early modern times V. Otamanovskyi has studied Vinnytsia as a type of Ukrainian city of the southern Right Bank of the 14th-17th centuries. The scientist raised the issue of the development of self-government in cities, in particular the influence of socio-economic factors, the evolution of the legal status of the Ukrainian city, the role of Magdeburg law in the life of the city. He concluded that the ancient cities of the 11th-13th centuries passed the same path of original development as Western European cities, and not the privileges of Magdeburg law determined the legal status of the city and forms of urban planning, but the level of craft and trade development of cities and the degree of its separation from agriculture.

\footnotetext{
${ }^{26}$ Крип’якевич І. П. Історія України. Львів: Вид-во «Світ», 1990. С. 134.
} 
Polish historiography of the 1920s and early 1930s of the 20th century showed the interest in the problem of urban planning in the GDL. Some aspects of the urban management on the Magdeburg law in Vilno, Brest, Polotsk, Desna, as well as in Lutsk have been revealed in the works of S. Kutsheba, G. Lovmyansky, I. Yavorsky. In a thorough article on the history of Volyn from 1340 to 1569, S. Zayonchkovsky linked the process of genesis of the bourgeoisie in the GDL, in particular in Volyn cities, with the spread of German law and the organization of public life "Western-style".

The period after the end of World War II was marked by increasing ideological pressure on the humanities, the development of campaigns against the Soviet intellectuals, which took various forms: the struggle against "cosmopolitanism" in the late 40's - early 50's, later against Ukrainian "nationalism" 60 - early 70's). All this has objectively led to a reduction in the research in the field of the Ukrainian history in general and the urban issues in particular.

Among the isolated publications of the postwar period one should mention a long article by O. Baranovych "New city of Western Ukraine in the sixteenth century. (Foundation of Starokonstantiniv)" (1951). On the example of the city of Starokostiantyniv, the author showed the process of founding this type of city in the 16th century by legally securing of the city, building a castle, as well as attracting colonists to it with the provision of appropriate benefits.

Since the 1960s, Soviet historiography the interest of the scientific community in the history of the Grand Duchy of Lithuania has been revived. Some aspects of the development of Volyn cities, questions of origin, nature and role of Magdeburg law in them were raised in historiographical studies.Russian historians. Khoroshkevich (1966) and Y. Klokman (1966), as well as Ukrainian scholars, in particular G. Shvydko considered the historiography of the cities of Ukraine in the 16th and 18th centuries $(1975,1979)$. The researchers acknowledged that their main focus was on the socio-economic history of the cities,since such research was crucial to elucidating the genesis of capitalist relations in Russia. 
The first significant investigation of Soviet historiography in this area was the work of V. Pashuto "Education of the Lithuanian State" (1959), although it only partially touched on the organization of power in the cities of Volyn. V. Otamanovskyi continued to study self-government in the cities of Ukraine of the 14th-16th centuries. Against the background of socio-economic development of Ukrainian cities, the researcher showed the evolution of their legal status and structure in Magdeburg law.

O. Kompan's work "Cities of Ukraine in the Second Half of the 17th Century" is of some interest for research (1963). Her materials make it possible to trace the trends of socio-economic and socio-political development of Volyn cities, in particular in terms of the organization of municipal self-government and the activities of workshops. Noting the peculiarities of the bourgeoisie of Ukrainian cities, O. Kompan noted that the bourgeoisie was a stratum in many respects different from the peasantry, although it originated from its environment. However, in Ukraine this difference did not appear as clearly as in more developed countries.

O. Kompan's research is characterized by a balanced approach to the role of Magdeburg law in the life of Ukrainian cities. The author rightly noted that the Magdeburg law was a natural stage of the development for Ukrainian and Polish cities. The cities at a certain stage of their development in the struggle against the feudal lords began to demand a separate organization and jurisdiction, i.e. the right to selfgovernment. In Western Europe, this was Magdeburg law. At the time when the cities of the GDL due to socio-economic and political development felt the need for such a law, it has already existed in neighboring countries and the cities took it as a model, but in the process of life Magdeburg law here has changed according to local circumstances and traditions. Thus, "Magdeburg law in Ukraine cannot be considered as something artificial, planted from above without internal need. But its consequences had both positive and negative sides" 27 .

${ }^{27}$ Компан О. С. Міста України в другій половині XVII ст. Київ: Вид-во АН УРСР, 1963. C. $116-117$. 
Since the 60's of the 20th century medievalists have begun to realize the history of small towns as an independent problem, because in the Middle Ages small towns predominated in the general mass of urban settlements. The problem of the different types of medieval Ukrainian cities studying was posed by Ya. Isayevych. The scientist noted that the history of the Ukrainian city cannot be created without writing the history of medium and small cities, where the majority of the urban population lived. On the example of one of the important centers of handicrafts and trade in the Ukrainian Carpathians the royal city of Drohobych, whose trade links stretched to Kholm, Dnieper, Volyn, the researcher raised the issue of the Ukrainian cities management in general. The reasoned conclusions on the organization of administration under Magdeburg law on the example of one city serve as a guide in finding the necessary information to study other cities with Magdeburg law; they provide a scientific basis for the abandoning and comparing of the activities of municipal authorities in different cities of Ukraine, in particular Volyn ones.

The clarification of the trend of industrial development, and at the same time changes in the social structure, organization of urban selfgovernment in Ukrainian cities are contained in the monograph of Lviv scientist J. Kis "Lviv industry in the period of feudalism (13-14 centuries)" (1968). It analyzes in detail the activities of craft shops, their integration into the system of municipal self-government, which operated on the basis of Magdeburg law. The activity of Lviv workshops was directly related to the organization of guild crafts in Volyn cities, since Lviv was the "senior city" for the cities and towns of Rus, Volyn and Podil voivodships, and its guild charters were a model for them.

Unlike the representatives of the Kyiv historical school, J. Kis generally positively assesses the role of Magdeburg law in the development of the urban community. According to the researcher, this law in the 15th-17th centuries in conditions of economic weakness of Ukrainian cities, immaturity of the bourgeoisie, the powerlessness of the central government in the period of aristocratic autocracy and anarchy gave them (though often limited) the right to immunity, independence 
from government officials, saved cities from complete subjugation by the nobility, from economic ruin. At the same time, German law accelerated the formation of the municipal government forms, helped the organization of small producers, contributed to the development of trade and economic relations ${ }^{28}$.

The source works of M. Kowalski under the general title "Source Studies and Archaeography of the History of Ukraine in the 16th - First Half of the 17th Century"; parts 1-4 (1977-1979) are quite valuable for covering the topic of urban self-government. They directly touched upon the problems of self-government organization in Volyn cities. The scholar started a thorough study of the act books of city, zemstvo, tribunal, magistrate and other courts as important historical sources. The merit of the scientist before science lies in the fact that he initiated the study of grodski (castle) books as sources on the history of Ukraine in the 16th-first half of the 17th century, when such work was not carried out and this initiative was not supported. He carried out a source analysis of location and Magdeburg privileges in Ukrainian cities. He carried out a source analysis of location and Magdeburg privileges in Ukrainian cities. The introduction into scientific circulation of previously unknown texts of these privileges, primarily from the books of Lithuanian metrics, their analysis and comparison with previously published sources allowed the author to explore further such important issues as the history of settlements, obtaining urban status and self-government, dating of the cities and towns, including Volyn ones and others. The identification of such aspects made it possible to determine more substantially the essence of the policy of the Grand Ducal government in relation to the cities and the limited functioning of Magdeburg law and its institutions in the lands of Ukraine and Volyn. Thus, the conducted by the scientist analysis of the sources on the history of Lutsk 16th - the first half of the 17th century in the documents LM not only enriched the source base on the history of the city, but also identified the priority areas of research of management in cities.

${ }^{28}$ Кісь Я. П. Промисловість Львова у період феодалізму (XIII-XIX ст.). Львів: Вид-во Львів. ун-ту, 1968. С. 5. 
It is worth noting the work of scientists in the study of such an important medieval source as the Lithuanian metrics, because it contains a large number of documentary evidence on the history of Volyn cities in the 15 th and 16th centuries. A significant contribution to the study of LM was made by the Soviet and Russian researcher A. Khoroshkevych, who in many of her works identified the current tasks of the source study of LM, as well as many specific issues on the history of GDL, including self-government in GDL [491-493, 495]. Of the importance for the research are the works of Dnipropetrovsk researcher S. Abrosimova on the analysis of LM materials to reflect in them the development of Ukrainian cities in the first half of the sixteenth century.

Valuable for the study of the problem of organization of power in Volyn in a certain period is the monograph by P. Sas "Feudal cities of Ukraine in the late 15 th -60 's of the 16th century" (1989) from the history of Ukrainian cities that were part of the GDL ${ }^{29}$. The scientist studied the socio-economic development of the cities of this region, their administrative system. He not only counted the number of cities, presented their typology by socio-economic characteristics, but also showed their fortification and defense significance. The author managed to analyze the economic development, social and ethno-confessional structure of the urban population, the development of crafts and trading, trade, organization of workshops. Considerable attention was paid to the legal status of cities, their administrative structure, and the traditions of urban self-government in Magdeburg law. He managed to show the practice of the functioning of Magdeburg law in Lutsk and Volodymyr, to a lesser extent in Kovel. There were revealed not only the general tendencies of development of city self-government on the Magdeburg law in the Ukrainian cities, but also the problems which arose in relations between separate branches of the power, in particular between Vogt and the council. At the same time, some problems of self-government in cities, due to the tasks and volume of the publication, did not find

${ }^{29}$ Сас П. М. Феодальные города Украины в конце XV - 60-х годах XVI в. Київ: Наук. думка, 1989. 
thorough coverage, such as the relationship between the castle and the city governments, their structure and personnel, procedural issues, etc.

In general, Soviet historians have taken a step forward in the study of the medieval city. They raised the issues of economic, social, political, partly cultural development of cities in the regions of the Grand Duchy of Lithuania, their administrative and legal status, introduction and functioning in the cities of Magdeburg (German) law, etc. However, the researchers' attention was focused on the problems of economic development of cities and the class struggle of the population. The investigations of Soviet historians, which contained a significant amount of material and conclusions on the self-government of cities under Magdeburg law, were conducted, according to the Polish historian J. Bardakh, around "the actual borderline - separately for Lithuania, separately for Belarus" ${ }^{30}$ [526, p. 79]. This opinion was shared by the Belarusian historian M. Ulashchyk and the Polish researcher S. Alexandrovich ${ }^{31}$.

Some aspects of the socio-economic situation of Volyn cities, their management under Magdeburg law were covered in the works of famous Polish researchers J. Bardakh, M. Bogutska, S. Kuras, J. Okhmyansky, G. Samsonovich and others. Their works are valuable for clarifying of the general historical context, the political situation in Volyn of the time, the internal history of Volyn cities, in particular in Lutsk in the 15th century at the time of receiving Magdeburg Privilege, identifying the interest groups associated with its granting. The works of Polish, as well as Belarusian, Russian historians, in which the problems of introduction and dissemination of Magdeburg law in other regions of the GDL were studied, make it possible to identify similarities and differences in the regional development.

${ }^{30}$ Bardach J. Ustrój miast na prawie magdeburgskim w Wielkiem Księstwie Litewskiem do połowy XVII wieku. Bardach J. O dawnej i niedawnej Litwie. Poznań, 1988. S. 79 .

${ }^{31}$ Улащик Н. Н. Очерки по археографии и источниковедению истории Белоруссии феодального периода. Москва: Наука, 1973. С. 6-14; Alexandrowicz Stanislaw. Studia z dziejów miasteczek Wielkiego Księstwa Litewskiego.Torun:Wydawnictwo naukowe Uniwersytetu Mikolaja Kopernika, 2011. S. 218. 
Yu. Bardakh, in his work "O dawnej i niedawnej Litwie" ("About old and recent Lithuania") (1988) set the task of studying the dynamics of changes in the structure and development of the cities of the Grand Duchy of Lithuania under Magdeburg law. In investigations of the problem of urban self-government, the historian believed, it is necessary to ensure the historical and political integrity of the Grand Duchy of Lithuania, which included Lithuanian and Belarusian lands, and before the Union of Lublin in 1569 included also also Podlachia and Ukraine. Considering the origins and adaptation of Magdeburg law, its spread, characterizing the division of cities into privileged and unprivileged, freedoms and rights of burghers, the competence of Vogts and city officials, the activities of magistrates, he actively involved sources from the history of Volyn cities, especially Lutsk ${ }^{32}$.

Of the importance in comparative terms are the studies of the history of cities and bourgeoisie in Poland and the Grand Duchy of Lithuania, carried out in the 80 s of the 20th century by M. Bogutska and G. Samsonovych, in particular on the organization of self-government in cities on the basis of Magdeburg law and their socio-economic situation.

Revival of interest in the history of the Grand Duchy of Lithuania in general and, in Volyn in particular, among Ukrainian historians in the late 20th and early 21st centuries is due to the lack of thorough modern research on the history of cities in the region, inherited from Soviet policy of the history studying as the priorities of historical research were determined by the then idea of the messianic role of the Moscow state in the unification of Rus lands. With the independence of Ukraine there was a fundamental change in the paradigm of research on the history of the GDL, where the history of the cities of the Right Bank of Ukraine has become the subject of increased attention.

The first thorough historiographical study of the political history of the Grand Duchy of Lithuania problem, which also raises the issues of governance in the cities of Volyn, is the monograph of the Dnipropetrovsk historian V. Vasylenko "Political history of the Grand

\footnotetext{
${ }^{32}$ Bardach J. Ustrój miast.., 1988. S. 79, 84, 89, 97, 99.
} 
Duchy of Lithuania (before 1569) in East Slavic historiographies of the 19th - first half of the 20th century". (2006). Written on a new methodological basis with the use of modern methods of historical analysis and a wide range of sources, it contains information about the nature of urban governance in Volyn. The historian did not set the task of considering urban problems in the Ukrainian lands, but raises partly the issue of the Ukrainian cities' situation, the organization of their management on the basis of Magdeburg law: Lutsk, Volodymyr, Kremenets and other cities are the defense and administrative centers of the Grand Duchy of Lithuania. V. Vasylenko's analysis of the discussion that took place among historians at the turn of the 19th and 20th centuries became valuable for the history of Lutsk around the reasons for providing in the early 30's of the 15th century privileges on the Magdeburg law to the Ukrainian cities, in particular to Lutsk on October $30,1432^{33}$.

Contemporary Ukrainian historiography in the late 20th - early 21 st century was enriched with the research on the activities of local officials in Volyn in the 15th and 18thcenturies. Thus, the works of a famous modern Ukrainian medievalist N. Yakovenko "Ukrainian nobility since the end of the 14th- to the middle of the 17th century. Volyn and Central Ukraine" (1993, 2008), "An Essay on the History of Medieval and Early Modern Ukraine" (1997, 2006), provide an opportunity to imagine the realities of life at that time, to "comply" the activities of Volyn government officials into the context of late medieval social relations. According to the scientist herself, she set a task "to overturn the depopulation of the "national-state" paradigm of Ukrainian history, which is inhabited by the "doers" themselves - as if neither children are born nor the seasons change without them. To overturn the belief that everything is predetermined in history "for us and without us" by some mysterious "laws" that push if you step forward / back - then by group, if you love / hate - then unanimously. To overturn, after all, the fixation on

33 Василенко В. О. Політична історія Великого князівства Литовського (до 1569 р.) в східнослов'янських історіографіях XIX - першої половини XX ст. Дніпропетровськ: Нац. гірн. ун-т, 2006. С. 226-230. 
one's own victories and troubles - as if there was no wide world around, from where good or bad winds brought new relatives, new aspirations, new values" ${ }^{34}[512$, p. 9]. The object of the historian's attention was the origins and social structure of the Ukrainian nobility, its personal composition, legal and property status of elite groups, including Volyn officials [515]. The researcher paid attention to the problems of spreading of the city law in Ukrainian lands, including Volyn, calling this process a real "urbanization revolution", as Magdeburg law removed the urban community from the jurisdiction of the royal administration and introduced the elected self-government ${ }^{35}$ [512, p. 127]. Methodologically important are her conclusions about the peculiarities of the development of Volyn cities. N. Yakovenko believes that the Grand Duchy of Lithuania city has not undergone such a bright rebirth into a new open community as in Galician or Podolsk Rus. However, this does not mean that it did not develop. Since the 15th century the wave of urbanization in Volyn, which the historian, following M. Hrushevskyi, associated with the presence of large aristocratic land tenure is gaining strength: "the emergence of new cities was due primarily to the establishment of large land ownership of the dukes". However, their inhabitants are closely connected with the rural district and this, in turn, hampered the development of urban life as $\operatorname{such}^{36}$ [512, p. 167-169]. According to N. Yakovenko, with the exception of Lviv, in fact, there was no what we usually call "Magdeburg city" in Ukraine. Each city was self-governing in its own way, considering its status as "Magdeburg", and therefore, each city appears as a unique phenomenon with its own "Magdeburg",37. Therefore, the accumulation of regional research, including the example of the cities of Volyn, remains relevant.

34 Яковенко Н. М. Нарис історії середньовічної та ранньомодерної України. 3-тє вид., переробл. та розш. Київ: Критика, 2006. С. 9.

${ }^{35}$ Там само. С. 127.

${ }^{36}$ Там само. С. 167-169.

${ }^{37}$ Датування міст як проблема історичної урбаністики: європейський та український досвід: матеріали «круглого столу» 24 вересня 2008 р. За заг. ред. В. Г. Панченка. Київ: Інститут суспільних досліджень, 2008. С. 53-54. 
As you know, the system of public administration is concentrated in the cities, so the study of urbanization is not accidentally the subject of close attention of scientists. The monographs of the Lviv scientist A. Zayats "Urbanization process in Volyn in the 16th - first half of the 17th century" (2003), The city society of Volyn in the 16th - first half of the 17th century" (2019), concerning the problem of the city network of the region, conducting locations and its components, the basics of selfgovernment in the cities of Volyn are of great scientific interest. The author considers the place and role of the studied cities in the general context of urbanization in Volyn, pays attention to the order and priority of granting Magdeburg law to cities, etc. The issues of spatial location of cities, the role of castles as fortifications and centers of local government are of great scientific interest.

Among the works on the history of the Magdeburg law spread and functioning in the cities of Volyn in the late 15th - first half of the 17th century, in particular in Kremenets, Olyka, Lutsk, the work of Kyiv researcher N. Bilous should be mentioned. Her Monograph "Kyiv in the late fifteenth - in the first half of the seventeenth century. City Power and Self-Government" (2008) contains a lot of information on the history of city self-government not only in Kyiv, but also in Vilno, Krakow, and others, which served as a model for the introduction of city government in some cities of Volyn region ${ }^{38}$. Comparative analysis of government systems in Kyiv and Volyn makes it possible to recreate the specifics of the functioning of government in Volyn cities.

Ukrainian historians started to pay more attention to the study of the Volyn cities role and place in the processes of state building and socio-economic development of the Grand Duchy of Lithuania. Among them of importance are the investigations of the famous historian V. Atamanenko, which relate to the analysis of descriptive and statistical sources, especially inventories and audits of Volyn cities and castles. The materials of his articles make it possible to clarify the structure of

${ }^{38}$ Білоус Н. О. Київ наприкінці XV - у першій половині XVII століття. Міська влада і самоврядування. Київ: Вид. дім «Києво-Могилян. акад.», 2008. 358 с. 
handicraft production, directions of trade of local residents, quantitative and qualitative characteristics of the population of Lutsk, Volodymyr, Kovel and other cities in the second half of the 15 th - first half of the 16th century ${ }^{39}$.

The investigations of the American historian and archivist P. Kennedy Grimsted, modern Polish scientists (G. Blazzczyk, L. Korczak, Z. Noga, K. Pietkiewicz, R. Shchigel), Lithuanian scientists (A. Dubonis, Z. Käupa, J. Käupane, R. Petrauskas), Belarusian scientists (V. Voronin, S. Kalinin, M. Makarov, V. Menzhinskyi, A. Yanushkevich) promote to clarify the peculiarities of the self-government in Volyn in the comparative retrospective. Despite the fact that there are no special studies on the history of self-government in Volyn cities of the period under the study, there are only mentions of Volyn cities in the research on the history of cities in Poland, Lithuania, and Belarus. Modern researchers from Poland, Lithuania, and Belarus pay considerable attention to the publishing sources on the history of the GDL. In recent years, Vilnius has become the center of publication and active research of Lithuanian metrics. Lithuanian historians (Z. Käupa, Z. Käupane), not limited to the territory of modern Lithuania, also elaborate the problem of socio-economic development of cities and urban population of the GDL.

\section{CONCLUSIONS}

Thus, the study of the self-government organization problem in the cities of Volyn within the GDL had its own specifics due to the needs of the time. The real thorough scientific elaboration of the self-government

39 Атаманенко В. Б. Описи міст Волині середини XVI ст. Україна і Велике князівство Литовське в XIV-XVIII ст.: політичні, економічні, міжнаціональні та соиіокультурні відносини в загальноєвропейському вимірі. V Міжнар. наук. конф. Київ, Камянець-Подільський, 2017. С. 40-43; Атаманенко В. Б. Описово-статистичні джерела до історії населення Володимира другої половини XVI- першої половини XVII ст. Минуле $i$ сучасне Волині і Полісся: Місто Володимир-Волинський та Побужжя у світовій та украӥнській історії. Наук. зб. Вип. 55. Всеукр. наук. істор.-краєзнав. конф. 23 жовтня 2015, м. Володимир-Волинський / упорядн. А. Силюк, В. Пикалюк. Луцьк, 2015. С. 95-106 та ін. 
problem in Volyn cities became possible thanks to the activity of the Temporary Commission for analysis of ancient acts. The most important in terms of studying of the theory and practice of self-government of Ukrainian cities were the works of scientists of the second half - early 20th century M. Vladymyrskyi-Budanov, F. Taranovskyi, V. Antonovych, M. Hrushevskyi and others, who clarified the legal basis of selfgovernment in cities, their structure and functions. The significant contribution to the coverage of the influence of institutions of state power (governments of elders, marshals, locksmiths, city-provosts, etc.) on the system of municipal government was made by M. Lyubavsky. The attention of the mentioned scholars is mainly focused on the developed forms of self-government in the cities of the second half of the 16th and 17 th centuries, at the same time the activity of city governments, future magistrates until 1569 in Volyn cities was insufficiently covered.

The research of Soviet historians tended to analyze the socioeconomic development of Ukrainian cities in the context of the escalation of class contradictions there, the tendentious assessment of Magdeburg law, the role of the bourgeoisie as a social status, etc. The works of such scientists as M. Kovalskyi, O. Kompan, P. Sas, A. Khoroshkevych, G. Shvydko and others contributed to the expansion of the source base of scientific research, clarification of the specifics of the functioning of government and self-government in Volyn cities of the period under the study.

Modern Kyiv historians, such as N. Bilous, V. Polishchuk, N. Starchenko, N. Yakovenko, are active in considering the problem of the state authorities and local self-government in Volyn activity, which is largely due to the high professionalism of researchers and greater convenience for them in the use of funds of the CSHA of Ukraine. Scientists from Lviv (A. Zayats, M. Krykun, M. Kapral), Ostroh (V. Atamanenko), Dnipropetrovsk (S. Abrosimova, G. Shvydko) and others also made a significant contribution to the study of this problem. Their conceptual positions on many general issues of the GDL political history, analysis of Lithuanian metrics, Lutsk castle books, revisions of Volyn castles, and other descriptive and statistical materials make it 
possible to trace the genesis of the formation and evolution of state authorities in the GDL and self-government in Ukrainian cities.

Despite the relevant achievements of science in this field of knowledge, the current level of history of self-government in the cities of Volyn requires further research, in particular in terms of coverage of the city governments of Lutsk, Vladimir, Kovel, Ostrozhets and many others, procedures for their formation, activities, and diversification of functions between the board and the Lava, etc. Some issues of the specifics of selfgovernment in Volyn cities of different subordination - Grand Ducal and privately owned.

The involvement of a rich set of materials in scientific circulation, "new reading" of previously used sources significantly expands the understanding of the nature of socio-political and legal relations in society, the level of consciousness, moral and ethical values that prevailed in the late Middle Ages and early modern times in Volyn.

Thus, despite some investigations of domestic and foreign scholars, the study of the history of self-government in the cities of Volyn of this period requires further in-depth research, since municipal government in Volyn as a complex problem has not yet become the appanage of domestic historical science.

\section{SUMMARY}

The review of the scientific literature on the problem of selfgovernment in the cities of Volyn on the basis of Magdeburg law in the Grand Duchy of Lithuania has been carried out. It has been proved that the history of Volyn was first considered by Polish historians in the context of the general history of Poland. Within the framework of approving the concept of "one and indivisible Russia" and the activities of the Temporary Commission for the Analysis of Ancient Acts, the basis of many studies on the history of the cities of Volyn was laid. Two directions of research - historical-legal and historical-economic were formed in 60's and 70's of the 19th century. The Soviet period was not active in studying this problem. The achievements in source studies (M. Kowalski) were the exceptions. With the acquisition of independence 
there was a fundamental change in the paradigm of the Ukrainian cities and Volyn in particular research. The development of cities began to be considered in the context of Ukrainian national and state building with an emphasis on identifying common and special in the organization of selfgovernment in cities on a democratic basis and compliance with European practice of local self-government.

\section{REFERENCES}

1. Заяць А. Є. Урбанізаційний процес на Волині в XVI першій половині XVII століття. Львів: Добра справа, 2003. 205 с.

2. Codex diplomaticus Regni Poloniae et Magni Ducatus Lithuaniae in quo pacta, foedera, tractatus pacis... nunc primum ex archivis publicis eruta ac in lucem protracta exhibuntur / [ed.] M. Dogiel. T. 1, 4, 5. Vilnae, 1758-1759.

3. Naruszewicz A. Historya narodu polskiego, od początku chrześciaństwa. Warszawa, 1780-1786 ; Londyn 1836-1837 ; Kraków, 1859-1860.

4. Максимович М. А. Собрание сочинений. Киев: Тип. М. П. Фрица, 1876. Т. 1.847 с.; 1876. Т. 2.524 с.; 1880. Т. 3.743 с.

5. Иванишев Н. Д. Сочинения, изданные иждивением Университета св. Владимира. Отд. 1-2. Киев: Унив. тип, 1876. 463 с.

6. Перлштейн А. Луцк и его древности. Временник Московского общества истории и древностей российских. 1851. Кн. 9. С. 30-45.

7. Леонтович Ф. И. Очерки истории литовско-русского права. Образование территории Литовского государства. Санкт-Петербург: Тип. В. С. Балашева, 1894. 400 с.

8. Владимирский-Буданов М. Ф. Немецкое право в Польше и Литве. Журнал министерства народного просвещения (ЖМНП). 1868. Ч. CXXXIX. C. 467-554; Ч. CXL. С. 519-586; 772-833.

9. Тарановский Ф. В. Обзор памятников магдебургского права Западно-Русских городов литовской эпохи. Историкоюридическое исследование. Варшава: Тип. Варш. уч. округа, 1897. $201 \mathrm{c}$. 
10. Бершадский С. А. Литовские евреи. История их юридического и общественного положения в Литве от Витовта до Люблинской унии: 1388-1569. Санкт-Петербург: Тип. М. М. Стасюлевича, 1883. $431 \mathrm{c.}$

11. Левицкий О. И. О судьбе древних актових книг и собрания их в центральных архивах. Чтения в историческом обществе Нестора-летописца. Киев: [б. и.], 1896. Кн. 10. С. 11-14.

12. Антонович В. Б. Предисловие. Архив Юго-Западной России, издаваемьй Временной комиссиею для разбора древних актов, учрежденной при Киевском, Подольском и Вольнском генерал-губернаторе. Ч. V. Т. 1. Акты о городах (1432-1798). Киев: Универ. тип., 1869. 636 с.

13. Грушевський М. С. Історія України-Руси. Т. V. Суспільно-політичний і церковний устрій і відносини в українськоруських землях XIV-XVII ст. Київ: Наукова думка, 1994. 704 с.

14. Довнар-Запольский М. В. Государственное хозяйство Великого княжества Литовского при Ягеллонах. Киев: Тип. император. ун-та Св. Владимира, 1901. Т. І. 807 с.

15. Любавский М. К. Областное деление и местное управление Литовско-Русского государства ко времени издания первого Литовского статута. Исторические очерки. Москва: Университет. тип., 1892. 884 с.

16. Якубовский И. В. Земские привилеи Великого княжества Литовского. Журнал министерства народного просвещения. 1903. № 4. С. 239-278; № 6. С. 245-303.

17. Василенко В. О. Політична історія Великого князівства Литовського (до 1569 р.) в східнослов'янських історіографіях XIX першої половини XX ст. Дніпропетровськ: Нац. гірн. ун-т, 2006. $659 \mathrm{c}$.

18. Дружчыц В. Магістрат у беларускіх местах 3 майдэборскім правам у XV-XVII сталецыцях. Запіскі Адделу гуманіт. навук Iнстытута Беларускае культуры. Кн. 8. Працы клясы гісторыі. Т. 3. Минск: [б. и.], 1929. С. 377-458. 
19. Крип'якевич І. П. Історія України. Львів: Вид-во «Світ», 1990. $520 \mathrm{c}$.

20. Компан О. С. Міста України в другій половині XVII ст. Київ: Вид-во АН УРСР, 1963. 388 с.

21. Кісь Я. П. Промисловість Львова у період феодалізму (XIII-XIX ст.). Львів: Вид-во Львів. ун-ту, 1968. 223 с.

22. Сас П. М. Феодальные города Украины в конце XV 60-х годах XVI в. Київ: Наук. думка, 1989. 232 с.

23. Bardach J. Ustrój miast na prawie magdeburgskim w Wielkiem Księstwie Litewskiem do połowy XVII wieku. Bardach J. O dawnej i niedawnej Litwie. Poznań, 1988. S. 72-119.

24. Улащик Н. Н. Очерки по археографии и источниковедению истории Белоруссии феодального периода. Москва: Наука, 1973. 293 с.

25. Alexandrowicz Stanislaw. Studia z dziejów miasteczek Wielkiego Księstwa Litewskiego. Torun: Wydawnictwo naukowe Uniwersytetu Mikolaja Kopernika, 2011. $442 \mathrm{s.}$

26. Яковенко Н. М. Нарис історії середньовічної та ранньомодерної України. 3-тє вид., переробл. та розш. Київ: Критика, 2006. $584 \mathrm{c}$.

27. Датування міст як проблема історичної урбаністики: європейський та український досвід: матеріали «круглого столу» 24 вересня 2008 р. За заг. ред. В. Г. Панченка. Київ: Інститут суспільних досліджень, 2008. 88 с.

28. Білоус Н. О. Київ наприкінці XV - у першій половині XVII століття. Міська влада і самоврядування. Київ: Вид. дім «Києво-Могилян. акад.», 2008. 358 с.

29. Атаманенко В. Б. Описи міст Волині середини XVI ст. Україна і Велике князівство Литовське в XIV-XVIII ст.: політичні, економічні, міжнаціональні та соціокультурні відносини в загальноєвропейському вимірі. V Міжнар. наук. конф. Київ, Камянець-Подільський, 2017. С. 40-43.

30. Атаманенко В. Б. Описово-статистичні джерела до історії населення Володимира другої половини XVI - першої половини 
XVII ст. Минуле і сучасне Волині і Полісся: Місто ВолодимирВолинський та Побужжя у світовій та украӥнській історії. Наук. зб. Вип. 55. Всеукр. наук. істор.-краєзнав. конф. 23 жовтня 2015, м. Володимир-Волинський. упорядн. А. Силюк, В. Пикалюк. Луцьк, 2015. C. $95-106$.

\section{Information about the author:}

Bortnikova A. V.,

Doctor of Political Science, Associate Professor, Professor at the Department of World History and Philosophy, Lesya Ukrainka Eastern-European National University 13, Volya Avenue, Lutsk, 43025, Ukraine 